\title{
Development of Living Values (Responsibilities) Assessment Instryments in Learning Physics
}

\author{
$1^{\text {st }}$ Siti Sarah \\ Physics Education, Sains Al \\ Quran UNY \\ Yogyakarta, Indonesia \\ St.sarah44@gmail.com
}

\author{
$2^{\text {nd }}$ Zuhdan Kun Prasetyo \\ Science Education Yogyakarta \\ State University \\ Yogyakarta, Indonesia \\ zuhdan@uny.ac.id
}

\author{
$3^{\text {rd }}$ Insih Wilujeng \\ Science Education Yogyakarta \\ State University \\ Yogyakarta, Indonesia \\ insih@uny.ac.id
}

\begin{abstract}
The circulation of fake cosmetics, fake drugs, and fake vaccines as well as drugs abuse showed the low sense of responsibility of certain individuals. It could lead to big danger such as low quality of life and even death. If left unattended. Various precautions have been taken in terms of regulation of manufacture, distribution and prevention of abuse. However, prevention efforts have not been found in terms of the attitude of responsibility. So far there is no instrument to assess valid and reliable responsibilities. Physics learning in senior high school (SHS) has full potential to nurture living values such as responsibility. Therefore, this study aimed to produce valid and reliable instruments to measure responsibility in physics learning. This research employs research and development methods with 1167 parents from students studying physics at SHS as the respondents. The data were collected by using interviews, observation, and questionnaires. Data analysis was in the form of validity and reliability tests. The validity of the contents of the instrument was in the criteria of very good and fairly good. All questionnaire items were satisfactory in term of construct validity. The value of Cronbach's alpha for the questionnaire was 0.706 which was included in the good category.
\end{abstract}

Keywords: assessment, living values, responsibility, physics learning

\section{INTRODUCTION}

National Education Standards Agency and The Ministry of National Education includes physics as a subject in senior high schools (SHS) which are full of living values in the learning process in addition to knowledge (cognitive) and skills (psychomotor). However, the facts show that there are not many students who have living values [1], [2].

Ary Ginanjar Agustian states that the living values are easily internalized and implemented basic values that form characters [3]. The living values contributes $26 \%$ to the formation of national character [4], [5]. Implementing living values through habituation in schools can improve the character of students by $42.1 \%$ [6], [7]. As the inventor of LVE (Living Values Education) model, Tilman provides ways to grow the living values by encouraging each person to observe the actions of each different person and to propose how they can make differences [8].

There are 13 living values that can be developed in Indonesia, namely being religious, honesty, tolerance, good behavior, discipline conscientiousness, being creative, being independent, nationalism, appreciating achievement, cooperativeness, and responsibility [4]. One of the values of life that currently needs to be nurtured urgently is responsibility. This is because there have been many behaviors which show lack of responsibility, such as the circulation of narcotic, fake cosmetics, and fake vaccines. If such problems are not immediately prevented, there will be a decline in the quality of life of the community and may cause mortality.

Data from the National Narcotics Agency (Badan Narkotika Nasional - BNN) shows that around 3.4 million people $(1.77 \%)$ in Indonesia are abusing narcotics and most of them are in productive ages, i.e. 10-59 years old [9]. Furthermore, The Head of Police General of BNN Hohny $\mathrm{P}$ Latupeirissa said that Indonesia is currently the largest market in Asia [10]. Drug problems are not only happening in Indonesia. In 2002, Southeast Asia and West Asia had serious narcotics problems which was even worse than Indonesia. This was because the three largest prohibited opium producers in the world, namely Afghanistan, Myanmar and Laos, had increasing amount of opium and heroin production [11].

Besides drugs abuse, problems caused by irresponsibility also include fake cosmetics and fake vaccines transactions. During 2018, the Republic of Indonesia Food and Drug Supervisory Agency (Badan Pengawas Obat dan MakananBPOM) has seized illegal cosmetics worthed Rp. 106.9 billion [12]. The investigation results of the Police Headquarters Criminal Investigation Agency 
reveal ed that the practice of fake viral vaccines transactions has been running since 2003 [13].

The transaction of narcotics, fake cosmetics and fake vaccines transactions have been occurring since centuries ago but it keeps widespreading. Provisions and laws have been forced but those are never enough to stop the irresponsible actions. Therefore, this study aims to develop instruments to assess responsibility in early age. The instruments are expected to a reference to observe students' responsibility at school and in the family. Hopefully, the irresponsible behaviors can be detected as early as possible and thus prevent further criminal acts.

\section{METHODOLOGY}

The design of this study is research and development. There were eight steps of research carried out, namely (1) determining instruments specifications, (2) writing the instruments, (3) determining the measurement scale, (4) determining the scoring system, (5) reviewing the instrument, (6) conducting trials, (7) analyzing instruments, and (8) assembling instruments. The study was conducted in seven senior high schools and one Madrasa Aliya (Islamic senior high school) in Wonosobo District. The respondents were 1167 parents whose children took physics course in school.

The data were collected by using questionnaires, observations, and interviews. Data analysis was carried out by conducting validation (content and construct) and reliability tests. Construct validation was analyzed through analysis of factors while the reliability was observed from the alpha Cronbanch value.

\section{RESULTS}

The following are the eight steps of the research.

1. Determining instruments specifications

The present study is a follow-up of studies conducted in 2013 and 2014. The studies produced a valid and reliable living values (responsibility) assessment instrument for high school physics learning [14]. However, the previous studies time was limited within school environment. The present study attempted to develop the assessment not only in school environment but also in family environment through the involvement of the parents for assessing students' sense of responsibility.

\section{Writing the Instruments}

"Responsibility" in this research is defined as the attitude and behavior of a person to carry out their duties and obligations as they should to themselves, society and their natural, social, and cultural environment, the state, and God. Indicators of responsibility include: (1) doing the job properly and (2) accepting the risk of the action taken.

Each indicator was then elaborated on each instrument item, namely questionnaire sheet, observation sheet, and interview guide sheet. The questionnaire sheet contained 10 items which were divided into positive and negative statements which were should be filled in by parents. Positive and negative statements of the indicators were not put randomly with the intention of the respondent not to answer recklessly. Observation sheets were filled in by the observers while observing the students' sense of responsibility in physics learning. The interview guide sheet was applied to the students and teachers.

3. Determining the measurement scale

Likert scale was used in composing the questionnaire items. The observation sheet was prepared by using a scale based on the rubric that has been compiled.

\section{Determining the scoring system}

The Likert scale used in the questionnaire consists of 4 values, namely $1=$ never, $2=$ rarely, $3=$ often, 4 = always. Observation sheet was prepared by using a scale of $1-4$ based on the rubric that had been compiled. The more activity the respondent did, the respondent's score was closer to 4 .

\section{Reviewing the instruments}

The instrument review was carried out by 3 lecturers who had expertise in the field of physics learning and 3 high school physics teachers. The review was carried out to assess several things, such as (1) whether the questions or statements were in accordance with the indicators, 2) whether the language used was communicative and using the correct grammar, 3) whether the questions or statements were not biased, 4) whether the instrument format was interesting to read, 5) whether the number of items was appropriate so that it would not be boring to answer it. Here are the results:

\section{a. Questionnaire}

The assessment of the questionnaire included three aspects, namely content, language and construction. The following is the data of the validation score conversion of the questionnaire on students' sense of responsibility. 
Table 1. Conversion of validation score for questionnaire on the sense of responsibility

\begin{tabular}{|c|c|c|c|}
\hline Aspect & Score range & Value & Category \\
\hline \multirow{5}{*}{ Contents } & $x>4,20$ & A & Very good \\
\hline & $3,40<X \leq 4,20$ & $\mathrm{~B}$ & Good \\
\hline & $2,60<X \leq 3,40$ & $\mathrm{C}$ & Good enough \\
\hline & $1,80<X \leq 2,60$ & $\mathrm{D}$ & Not good \\
\hline & $X \leq 1,80$ & $\mathrm{E}$ & Very bad \\
\hline \multirow{5}{*}{ Language } & $x>12,60$ & $\mathrm{~A}$ & Very good \\
\hline & $10,20<X \leq 12,60$ & $\mathrm{~B}$ & Good \\
\hline & $7,80<X \leq 10,20$ & $\mathrm{C}$ & Good enough \\
\hline & $5,40<\mathrm{X} \leq 7,80$ & $\mathrm{D}$ & Not good \\
\hline & $X \leq 5,40$ & $\mathrm{E}$ & Very bad \\
\hline \multirow{5}{*}{ Construction } & $x>4,20$ & A & Very good \\
\hline & $3,40<X \leq 4,20$ & $\mathrm{~B}$ & Good \\
\hline & $2,60<\mathrm{X} \leq 3,40$ & $\mathrm{C}$ & Good enough \\
\hline & $1,80<\mathrm{X} \leq 2,60$ & $\mathrm{D}$ & Not good \\
\hline & $X \leq 1,80$ & $\mathrm{E}$ & Very bad \\
\hline
\end{tabular}

Referring to table 1 the results of expert validation on the responsibility questionnaire shows that the aspect of content is 2.67 (fairly good), language aspect is 15 (very good) and construction aspect is 5 (very good). The validation results from the physics teachers show content aspects of 4.5 (very good), language aspect of 13.5 (very good), and construction aspect of 4.5 (very good). The results of the assessment were then used as the basis to improve the content of the questionnaire.

b. Observation sheet

Observation sheets are used to measure responsibility in physics learning at school. The assessment included three aspects, namely content, language and construction. The following is the data of observation sheet validation scores conversion after converted to five-scale values.

Table 2. Conversion of the observation sheet validation score on the sense of responsibility

\begin{tabular}{|c|c|c|c|}
\hline Aspect & Score range & Value & Category \\
\hline \multirow{4}{*}{ Contents } & $\mathrm{x}>4,20$ & $\mathrm{~A}$ & Very good \\
\cline { 2 - 4 } & $3,40<\mathrm{X} \leq 4,20$ & $\mathrm{~B}$ & Good \\
\cline { 2 - 4 } & $2,60<\mathrm{X} \leq 3,40$ & $\mathrm{C}$ & Good enough \\
\cline { 2 - 4 } & $1,80<\mathrm{X} \leq 2,60$ & $\mathrm{D}$ & Not good \\
\cline { 2 - 4 } & $\mathrm{X} \leq 1,80$ & $\mathrm{E}$ & Very bad \\
\hline \multirow{5}{*}{ Language } & $\mathrm{x}>12,60$ & $\mathrm{~A}$ & Very good \\
\cline { 2 - 4 } & $10,20<\mathrm{X} \leq 12,60$ & $\mathrm{~B}$ & Good \\
\cline { 2 - 4 } & $7,80<\mathrm{X} \leq 10,20$ & $\mathrm{C}$ & Good enough \\
\cline { 2 - 4 } & $5,40<\mathrm{X} \leq 7,80$ & $\mathrm{D}$ & Not good \\
\cline { 2 - 4 } & $\mathrm{X} \leq 5,40$ & $\mathrm{E}$ & Very bad \\
\hline \multirow{5}{*}{ Construction } & $\mathrm{x}>12,60$ & $\mathrm{~A}$ & Very good \\
\cline { 2 - 4 } & $10,20<\mathrm{X} \leq 12,60$ & $\mathrm{~B}$ & Good \\
\cline { 2 - 4 } & $7,80<\mathrm{X} \leq 10,20$ & $\mathrm{C}$ & Good enough \\
\cline { 2 - 4 } & $5,40<\mathrm{X} \leq 7,80$ & $\mathrm{D}$ & Not good \\
\hline & $\mathrm{X} \leq 5,40$ & $\mathrm{E}$ & Very bad \\
\hline
\end{tabular}


Referring to Table 2, experts' validation on the observation sheet shows the score of 4.33 (very good) for content aspect, 14 (very good) for language aspect and 13.33 (very good) for construction aspect. The validation results from physics teachers show the score 4.5 (very good) for content aspect, 13.5 (very good) for language aspect, and 15 (very good) for construction aspect. Since all aspects were included in very good category, the observation sheet did not need to be changed.

c. Interview guideline sheet

The interview was used as additional data to determine students' sense of responsibility. The assessment of interview guildeline sheet included 3 aspects, namely content, language and construction. The following is the data of the interview guide validation score conversion.

Table 3. Conversion of interview guide validation scores to measure the sense of responsibility

\begin{tabular}{|c|c|c|c|}
\hline Aspect & Score range & Value & Category \\
\hline \multirow{4}{*}{ Contents } & $\mathrm{x}>4,20$ & $\mathrm{~A}$ & Very good \\
\cline { 2 - 4 } & $3,40<\mathrm{X} \leq 4,20$ & $\mathrm{~B}$ & Good \\
\cline { 2 - 4 } & $2,60<\mathrm{X} \leq 3,40$ & $\mathrm{C}$ & Good enough \\
\cline { 2 - 4 } & $1,80<\mathrm{X} \leq 2,60$ & $\mathrm{D}$ & Not good \\
\cline { 2 - 4 } & $\mathrm{X} \leq 1,80$ & $\mathrm{E}$ & Very bad \\
\hline \multirow{5}{*}{ Language } & $\mathrm{x}>12,60$ & $\mathrm{~A}$ & Very good \\
\cline { 2 - 4 } & $10,20<\mathrm{X} \leq 12,60$ & $\mathrm{~B}$ & Good \\
\cline { 2 - 4 } & $7,80<\mathrm{X} \leq 10,20$ & $\mathrm{C}$ & Good enough \\
\cline { 2 - 4 } & $5,40<\mathrm{X} \leq 7,80$ & $\mathrm{D}$ & Not good \\
\cline { 2 - 4 } & $\mathrm{X} \leq 5,40$ & $\mathrm{E}$ & Very bad \\
\hline \multirow{5}{*}{ Construction } & $\mathrm{x}>4,20$ & $\mathrm{~A}$ & Very good \\
\cline { 2 - 4 } & $3,40<\mathrm{X} \leq 4,20$ & $\mathrm{~B}$ & Good \\
\cline { 2 - 4 } & $2,60<\mathrm{X} \leq 3,40$ & $\mathrm{C}$ & Good enough \\
\cline { 2 - 4 } & $1,80<\mathrm{X} \leq 2,60$ & $\mathrm{D}$ & Not good \\
\cline { 2 - 4 } & $\mathrm{X} \leq 1,80$ & $\mathrm{E}$ & Very bad \\
\hline
\end{tabular}

Referring to Table 3, experts' validation on the interview guidelines sheet shows the score of 2.67 (fairly good) for content aspect, 15 (very good) for language aspect and 5 (very good) for construction aspect. The validation results from the physics teacher show the score for content aspect is 4.5 (very good), the score for language aspect is 13.5 (very good), and the score for construction aspect is 4.5 (very good). According to the results of the assessment, several interview guide items need to be improved in terms of content based on expert advice.

\section{Conducting trials}

Instrument trials were only carried out on a questionnaire filled out by parents. The trials were conducted on 1167 parents of students from 7 senior high schools and 2 Madrasah Aliyah who studied physics in Wonosobo
Regency. The trials aim to determine the construction validity and the instrument reliability.

\section{Analyzing the instruments}

The instrument analysis was conducted by employing SPSS 25 software for windows. The test of analysis requirements using Kaiser Meyer Olkin regarding the measure of sampling adequacy of the KMO MSA obtained a value of 0.805 . It means that the data had a good measure of sampling adequacy since the value of KMO MSA was greater than 0.5. Then the analysis was proceeded to find out the factors of sense of responsibility development. Based on the factor analysis in the anti image correlation (AIC) table, no value below 0.5 (Table 4) was found. Therefore, all responsibility items are stated to fulfill construct validity. 
Tabel 4. Anti-image Matrices

\begin{tabular}{l|l|l|l|l|l|l|l|l|l|} 
Item1 & Item4 & Item5 & item8 & Item10 & Item2 & Item3 & Item6 & Item7 & Item9 \\
\hline
\end{tabular}

\begin{tabular}{|c|c|c|c|c|c|c|c|c|c|c|c|}
\hline \multirow{10}{*}{$\begin{array}{l}\text { Anti-image } \\
\text { Correlation }\end{array}$} & Item1 & $.790^{a}$ & -.103 & -.028 & -.033 & -.074 & .043 & .010 & -.056 & -.135 & .030 \\
\hline & Item4 & -.103 & $.857^{a}$ & -.122 & -.191 & -.096 & .028 & -.161 & -.070 & -.008 & -.097 \\
\hline & Item5 & -.028 & -.122 & $.813^{a}$ & -.140 & -.158 & .023 & .058 & -.052 & -.059 & -.012 \\
\hline & Item8 & -.033 & -.191 & -.140 & $.839^{a}$ & -.126 & .022 & -.241 & -.084 & -.005 & -.068 \\
\hline & Item10 & -.074 & -.096 & -.158 & -.126 & $.873^{a}$ & -.020 & -.104 & -.044 & -.052 & -.078 \\
\hline & Item2 & .043 & .028 & .023 & .022 & -.020 & $.522^{\mathrm{a}}$ & -.010 & .018 & -.381 & -.003 \\
\hline & Item3 & .010 & -.161 & .058 & -.241 & -.104 & -.010 & $.806^{a}$ & -.205 & .021 & -.227 \\
\hline & Item6 & -.056 & -.070 & -.052 & -.084 & -.044 & .018 & -.205 & $.859^{a}$ & -.084 & -.183 \\
\hline & Item7 & -.135 & -.008 & -.059 & -.005 & -.052 & -.381 & .021 & -.084 & $.650^{a}$ & -.159 \\
\hline & item9 & .030 & -.097 & -.012 & -.068 & -.078 & -.003 & -.227 & -.183 & -.159 & $.837^{\mathrm{a}}$ \\
\hline
\end{tabular}

a. Measures of Sampling Adequacy(MSA)

Reliability test showed the alpha Cronbach coefficient value of 0.706 with good criteria. Thus, the questionnaire was ready to be used to collect data in the field.

8. Assembling the instruments

Based on the analysis of the instruments, the instruments for measuring student's sense of responsibility in the form of questionnaires did not need to be changed.

\section{DISCUSSION}

The assessment instruments on responsibility in high school physics learning were compiled with reference to the characteristics of physics learning in senior high school. Physics as part of science is formed from scientific attitudes, scientific processes, and scientific products that are interrelated [15]. Responsibility is one of the scientific attitudes/living values that lead to the development of physics. Therefore, achievements on aspects of responsibility cannot be separated from scientific processes and scientific products.

The responsibility assessment instrument in physics learning is composed of 2 indicators. The 2 indicators are reflected in 3 instruments, namely questionnaire sheet, interview guide sheet, and observation sheet. The questionnaire sheet consists of 10 items and the observation sheet consists of 3 items which overall are taken from 2 indicators of responsibility, namely (1) doing the job properly and (2) accepting the risk of the action taken. The interviews are semi-open and have indicators similar to questionnaires.

There has never been a research on the development of instruments for assessing the sense of responsibility in learning science in high schools. There is only a book that examines the assessment of character education globally with responsibility as one of the studies [16]. However, the book has not explained the indicators of responsibility which are related to the context of physics learning. Whereas true science learning will lead students to be curious, logical, critical, creative, innovative, honest, confident, diversitytolerant, discipline, independent, responsible, environmentally caring, knowledge loving and to be a person having healthy lifestyle [17].

Instrument of living values, especially on responsibility, is expected to be used as a reference in measuring the level of responsibility by everyone, especially at the school and family through learning physics. Hopefully, irresponsible behaviors can be detected as early as possible and thus can be prevented from developing into an irresponsible culture.

For subsequent research, the researchers aspire to developing instruments for measuring the sense of responsibility through learning physics which are not only relevant at school and in family, but also in society. The society in this context are people who live near students' homes, such as neighbors including the surrounding environment. It is important to involve the society in assessing student's sense of responsibility since currently not many community members have a sense of responsibility in looking after nature. Such problem can be seen from the behavior of the people who throw garbage in the river and who are less concerned with environmental cleanliness. If it continues, the behavior can cause natural disasters such as landslides and floods. Ramsey states that social responsibility is a predetermined general goal of education, which is no longer avoided by science education. Science education cannot be confined in the laboratory; it must become an active part in the social environment, instead. In addition to the above factors, experts also recommend that the society should as well be involved in the development of instruments for measuring the sense of responsibility so that the 
future instruments will be able to assess it comprehensively [18].

\section{CONCLUSION}

The results of the study showed that the assessment instruments on the responsibility have fulfilled valid and reliable aspects. Questionnaire sheet was declared valid with very good criteria except the contents aspect which by experts was valued as fairly good. Observation sheet was declared valid with very good criteria. The interview guideline sheet was declared valid with very good criteria except the content aspect which by experts was valued as fairly good. The results of factor analysis in the questionnaire show that all questionnaire items meet construction validity. The alpha Cronbach questionnaire value is 0.706 which is in good category.

\section{Acknowledgement}

The authors would like to express gratitude to DPRM Ristekdikti for the financial support of the Research Award for Doctoral Dissertation in 2018 of the Budget Year Contract No. 001/LP3MUNSIQ/PDD/2018. Gratitude also goes to LP3M UNSIQ for the support.

\section{References}

[1]. BSNP. "Guidelines for Preparing Curriculum at the Education Unit Level for Primary and Secondary Education (Panduan Penyusunan Kurikulum Tingkat Satuan Pendidikan Jenjang Pendidikan Dasar dan Menengah)", Jakarta: BSNP, 2006.

[2]. Kemendiknas. "National Education and Character Development (Pengembangan Pendidikan dan Karakter Bangsa). Jakarta: Pusat Kurikulum, 2010.

[3]. D. Zuchdi, Z. K. Prasetya \& M. S. Masruri. "Integrated Character Education Model in School Culture Learning and Development (Model Pendidikan Karakter Terintegrasi dalam Pembelajaran dan Pengembangan Kultur Sekolah)". Yogyakarta: Multi Presindo, 2013.

[4]. K. Komalasari. "The Living Values-Based Contextual Learning to Develop the Students' Character". Journal of Social Sciences, vol 8, no 2, pp. 246-251, 2012.

[5]. S. Wening. Formation of Nation Character through Value Education (Pembentukan Karakter Bangsa Melalui Pendidikan Nilai). Jurnal Pendidikan Karakter, vol II no. I, pp. 55-65, 2012.

[6]. D. Saripudin \& K. Komalasari. "Living Values Education in School Habituation Program and Its Effect on Student Character Development". The New Educational Review, vol 39 no. 1, pp. 51-62, 2015.
[7]. K. Komalasari, D. Saripudin, \& L. S. Masyitoh. "Living Values Education Model in Learning and Extracurricular Activities to Construct the Students' Character". Journal of Education and Practice, vol 5, no 7, pp 166174, 2014.

[8]. D. Tillman. "Living Values Activities for Young Adults". Jakarta: Grasindo, 2004.

[9]. BNN Public Relation. "UNPAD: Tugas Kami Tak Hanya Mencetak Generasi Berkualitas, Tapi Juga Berkontribusi Dalam Upaya Pencegahan Narkoba". Diakses http://www.bnn.go.id/read/berita/18264/unpad -tugas-kami-tak-hanya-mencetak-generasiberkualitas-tapi-juga-berkontribusi-dalamupaya-pencegahan-narkoba, 2018.

[10]. N. Sari. "BNN: Indonesia Pasar Terbesar Penjualan dan Peredaran Narkoba di Asia", Diakses dari https://megapolitan.kompas.com/read/2018/02 /14/13273231/bnn-indonesia-pasar-terbesarpenjualan-dan-peredaran-narkoba-di-asia, 2018.

[11]. K. Kulsudjarit. "Drug Problem In Southeast And Southwest Asia". Ann. N.Y. Acad. Sci. 1025: pp. 446-457, 2004.

[12]. D. Aquina. "Sasar Millennials, Waspada Bahan Kosmetik Berbahaya Ini”. Diakses dari https://www.idntimes.com/news/indonesia/ind ianamalia/sasar-millennials-waspada-bahankosmetik-berbahaya-ini/full, 2018

[13]. Ferdiansyah, D. "View of Pharmacists Regarding Counterfeit Vaccines, Who is wrong? (Pandangan Apoteker Terkait Vaksin Palsu, Salah Siapa?" Majalah Farmasetika, vol 1 no 1, pp. 10-13, 2016

[14]. S. Sarah \& Maryono. "Development of Local Potential Learning Devices to Improve Living Values of High School Students in Wonosobo District (Pengembangan Perangkat pembelajaran Berbasis Potensi Lokal untuk Meningkatkan Living Values Peserta Didik SMA di Kabupaten Wonosobo)". Technoscientia, vol 6 no 2, pp. 185-194, 2014.

[15]. A. T. Collette \& E. L. Chiappette. "Science Instruction in The Middle and Secondary Schools". New York: Macmillan Publishing Company, 1994.

[16]. D. Mardapi. "Character Education Assessment (Penilaian Pendidikan Karakter)". Retrieved from http: http://staff.uny.ac.id/sites/default/files/tmp/Pe nilaian_karakter.pdf, 2010.

[17]. D. Chusnani. "Character Education Through Science (Pendidikan Karakter Melalui Sains)". Jurnal Kebijakan dan Pengembangan Pendidikan, vol 1 No 1, pp. 9-13, 2013.

[18]. J. Ramsey. "The Science Education Reform Movement: Implications for Social Responsibility". Science Education, vol 77 no 2: $\quad$ pp. 1993. 
